\title{
Does Collective Identity Presuppose an Other? On the Alleged Incoherence of Global Solidarity
} ARASH ABIZADEH McGill University

\begin{abstract}
7 wo arguments apparently support the thesis that collective identity presupposes an Other: the recognition argument, according to which seeing myself as a self requires recognition by an other whom I also recognize as a self (Hegel); and the dialogic argument, according to which my sense of self can only develop dialogically (Taylor). But applying these arguments to collective identity involves a compositional fallacy. Two modern ideologies mask the particularist thesis's falsehood. The ideology of indivisible state sovereignty makes sovereignty as such appear particularistic by fusing "internal" with "external" sovereignty; nationalism imagines national identity as particularistic by linking it to sovereignty. But the concatenation of internal sovereignty, external sovereignty, and nation is contingent. Schmitt's thesis that "the political" presupposes an other conflates internal and external sovereignty, while Mouffe's neo-Schmittianism conflates difference (Derrida) with alterity. A shared global identity may face many obstacles, but metaphysical impossibility and conceptual confusion are not among them.
\end{abstract}

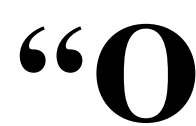
ur common humanity will never make us members of a single universal tribe. The crucial commonality of the human race is particularism" (Walzer 1992, 171). The particularist thesis expressed here by Michael Walzer, about the inherent particularity of collective identity, solidarity, or community, has become so widespread, commonplace, even self-evident, that it seems only to require being stated to win assent. It is a thesis with devastating implications for the possibility of a democratically legitimated cosmopolitan political order buttressed by a sense of identification or solidarity with humanity as a whole. ${ }^{1}$ As Dominique Schnapper (1994, 183) puts it: "Collective attachments are always affirmed in opposition to others. How could the sentiment of belonging to humanity be opposed to an Other? What subjective meaning could the idea of belonging to humanity have?" For Chantal Mouffe $(2000,13,41)$, the premise that "collective identities can only be established on the mode of an us/them" all but guarantees the anti-cosmopolitan conclusion that "there can never be a democracy of mankind." And again, according to David Miller (1989a), the view that community might embrace all of humankind "neglects the fact...that communities just are particularistic. In seeing myself as a member of a community, I see myself as participating in a particular way of life marked off from other communities by its distinctive characteristics" (67-68, emphasis mine). The particularist thesis apparently enjoys the status of a conceptual or metaphysical truth.

It is not just political theory, but also international relations, comparative politics, sociology, and anthropology, that regularly operate under the shadow of the

Arash Abizadeh is Assistant Professor, Department of Political Science, McGill University, 855 Sherbrooke Street West, Montreal, Quebec, Canada H3A 2T7.

I am grateful to Algernon Austin, Matthias Fritsch, Pablo Gilabert, Don Moon, Davide Panagia, Steve Saideman, and Khachig Tololyan for valuable comments on previous drafts.

1 "Cosmopolitan" in this essay refers to a conception of world citizenship and corresponding political institutions that assume humanity as a whole to be their subject. A canonical use of the word in this sense is that by Immanuel Kant ([1797] 1996). A more recent example is David Held 1995. particularist thesis. ${ }^{2}$ What I want to demonstrate here is that the particularist thesis, construed as a conceptual or metaphysical claim about the inherent nature of collective identity, solidarity, or community, does not stand to reason. It is one thing to say that identity presupposes difference; it is quite another to say that it presupposes an external other. Though so widely believed that it is rarely explicitly stated, much less defended, I shall demonstrate that the central arguments often thought to support the particularist thesis are fallacious. This is of capital importance because (even tacit) conceptual or metaphysical claims about collective identity set feasibility limits on both normative and empirical theories of politics-in this case, on normative theories of democracy and empirical theories of international relations and intergroup conflict.

The precise nature and significance of these feasibility limits depend on whether the particularist thesis is interpreted in a weaker or stronger way. The weaker way claims that a collectivity inherently requires the existence of some external other in contrast to which it can define itself. On this interpretation, some individuals must necessarily be excluded in order for a collectivity to exist. But this exclusion claim says nothing about the nature of the other-relation: that relation may be (some combination) of love, admiration, competition, resentment, hostility, etc. The second, stronger version of the particularist thesis goes further and specifies the nature of the relation to the other that the constitution of a collectivity supposedly requires: a relation of either antagonism or hostility. On this interpretation, a collectivity inherently requires adversarial exclusion: the existence of some external other against which it can define itself. This Schmittian version thus combines the exclusion claim with an adversary claim.

My initial focus is on the exclusion claim common to both versions. This component of the particularist thesis already has an important consequence for democratic theory: as the authors cited above suggest,

\footnotetext{
${ }^{2}$ For example, Brown 2001, 131, Huntington 1996, 20-21, 67, Schnapper 1994, 183, 106, and Eriksen 1995, 427, respectively.
} 
the particularist thesis raises an insurmountable barrier for cosmopolitan theories of democracy. Even theorists who do not explicitly state and defend the particularist thesis as a conceptual or metaphysical truth can be shown to subscribe to it tacitly by virtue of the putatively insurmountable anticosmopolitan normative conclusions they draw from it.

A second consequence is supplied by the stronger, adversarial version of the particularist thesis. The truth of the particularist thesis, on this interpretation, implies that intergroup relations are inherently characterized by friend/enemy conflict or antagonism. This is the point of departure for some of the most influential analyses of politics today-from so-called realist international relations theory ${ }^{3}$ to Samuel Huntington's "clash of civilizations" thesis. ${ }^{4}$ The upshot for normative democratic theory is, in turn, that democracy inherently depends on the identification of an enemy or adversary: if the particularist thesis rules out cosmopolitan democracy, its stronger version implies that global politics will always be characterized by clashes between enemies.

My argument against the first anticosmopolitan consequence is that the exclusion claim, far from reflecting a conceptual or metaphysical truth-one that raises an insurmountable barrier to overcoming the current Westphalian interstate political order-derives much of its apparent plausibility precisely from two features of the current Westphalian interstate order itself. For under the current interstate system, collective identities often do constitute themselves in contrast to an external other. But this is a contingent empirical fact: to reify it is to bar the possibility of overcoming the current anticosmopolitan order on the mistaken grounds that it is conceptually or metaphysically impossible to do so. I suggest that this reification is in part achieved by one of the Westphalian order's most powerful ideologies: the ideology of indivisible sovereignty. The particularist thesis, in other words, masks a reification of contingent processes of collective identity formation that, within the Westphalian order, it is tempting to redescribe ideologically as natural features of the universe. But it is the current anticosmopolitan order itself that ideologically imagines itself to be the necessary consequence of the nature of things, in part via the reification involved in the particularist thesis.

I similarly argue that the second, stronger viewthat intergroup relations are inherently conflictual-

\footnotetext{
${ }^{3}$ See, for example, Gilpin's (1986, 304-5) outline of the basic premises of the "realist" tradition.

${ }^{4}$ Huntington approvingly cites a fictional character to the effect that "there can be no true friends without true enemies" and that "unless we hate what we are not, we cannot love what we are." In his own words Huntington (1996) says that "for peoples seeking identity ... enemies are essential, and the potentially most dangerous enmities occur across the fault lines of the world's major civilizations" (20; cf. 21, 67). It is true that there is some evidence that Huntington does not think he is making an ahistorical claim about the nature of identity as such. But this historical sensitivity does not lead Huntington to revise his view that intergroup relations are inherently characterized by a friend/enemy dynamic; what is a contingent historical fact is simply that today's most politically salient friend/enemy "fault lines" are civilizational (20-29, 43).
}

mischaracterizes politics by reifying the causes of conflict and antagonism. These causes are not to be found in the inherent nature of collective identity-formation as such but, rather, in the contingent circumstances in which particular identities are formed, circumstances that it is the task of social scientists to investigate empirically. Theorists such as Mouffe, who ground their defence of agonistic democracy in collectivities' putative need for an other, are conflating the Schmittian language of alterity with the Derridean language of difference.

To expose these reifications is to open up the possibility of conceiving collective identity and, indeed, of (popular) sovereignty in cosmopolitan terms. This possibility runs counter to even some currents of constructivism in recent international relations theory. While "realists" have traditionally taken the exclusionary and adversarial nature of the state for granted, constructivists, because concerned to explain how states come to acquire their identities, have been open to the possibility that state identities need not be adversarial (Wendt 1992). But my analysis suggests that constructivists must be careful not to tacitly smuggle in assumptions about the inherently particularistic nature of state identity, assumptions that are all too tempting, thanks to the way in which state identity is shaped by the modern institution of sovereignty (cf. Jepperson et al. 1996, 45-47, 59, note 85). Otherwise, constructivists risk reproducing anew the "realist" conclusions that had motivated their critique in the first place. ${ }^{5}$

\section{THE PARTICULARIST THESIS AND THE ANTICOSMOPOLITAN THESIS}

The particularist thesis can be stated in terms of collective identity, solidarity, or community. It can even be stated in terms of cultures or collective modes of life, as when Anthony D. Smith $(1990,171)$ asserts that

we can only speak of cultures, never just culture; for a collective mode of life, or a repertoire of beliefs, etc., presupposes different modes and repertoires in a universe of modes and repertoires. Hence, the idea of a 'global culture' is a practical impossibility, except in interplanetary terms. ${ }^{6}$

Claims such as this, about the inherent nature of collective modes of life, speak of a conceptual or metaphysical truth not open to empirical falsification.

Mouffe $(2000,213)$ advances the particularist thesis explicitly in terms of identity when she says that "collective identities can only be established on the mode of an us/them." But solidarity and community are related to identity as well. In the ordinary sense of the word, community entails its members' identification with the group that constitutes it and, thus, entails a collective identity; in the stronger, moralized sense of the word, community also entails mutual concern among its members, i.e., a sense of solidarity, a disposition to "give each other's interests some noninstrumental

\footnotetext{
${ }_{5}^{5}$ For a nuanced constructivist approach that avoids this problem, see Wendt 1999, 2003.

${ }^{6}$ Smith $(1992,75)$ makes a similar point vis-à-vis identity.
} 
weight in their practical reasoning" (Mason 2000, 27). ${ }^{7}$ And though it is an empirical question, solidarityat least the kind required for democratic politics-is often thought to depend on a shared collective identity (Cohen 1999, 263). Since it turns out to be the crucial version of the thesis, I focus here on the particularist thesis stated in terms of collective identity.

Insofar as it is true that democratic politics requires, as its motivational basis, a sense of solidarity grounded in a shared collective identity, ${ }^{8}$ the particularist thesis implies that the cosmopolitan dream of a democratically legitimated and just global political order centered on a global human identity is in principle incoherent, or impossible on metaphysical grounds. The anticosmopolitan argument can be reconstructed as follows.

1. Collective identity (and the sense of solidarity centered on it) is inherently particular (i.e., any collective identity presupposes another collective identity that is its external other).

2. Therefore, a global human identity (and a sense of solidarity centered on it) is impossible.

3. Besides shared material interests, democratically legitimated politics requires solidarity centered on a shared collective identity capable of motivating such solidarity and joint political action.

4. Therefore, a democratic cosmopolitan political order is impossible.

Premise 1 is the particularist thesis (in its weak form) and Thesis 4 is the anticosmopolitan thesis routinely drawn as a consequence. Premise 3 articulates the empirical assumption that democracy requires a shared collective identity, or that it requires a sense of solidarity that in turn depends on shared identity. (The entire argument can also be restated in terms of "community" instead of "solidarity.") I do not concern myself with Premise 3: for the sake of argument I simply take it for granted. My thesis is that, independent of the truth or falsity of Premise 3, the four-step anticosmopolitan argument fails: Premise 1 is false. While individual identity may indeed be inherently particular, collective identity is not, and the arguments for Premise 1 proceed only by equivocating between these two senses of identity. There are undoubtedly many real-world obstacles facing the ancient cosmopolitan dream of global solidarity and a community of humankind. But conceptual incoherence or metaphysical impossibility is not one of them.

\section{HEGEL AND TAYLOR: THE RECOGNITION AND DIALOGIC ARGUMENTS}

The notion that identity either conceptually or metaphysically requires an external other has a long history, a history that certainly includes Rousseau's second

\footnotetext{
${ }^{7}$ See also Jaeggi $(2001,291)$, who argues that solidarity should be understood as a symmetrical "form of non-instrumental cooperation."

8 This is another widespread assumption. See, for example, Cohen 1999 and C. Taylor 1998.
}

Discours and Émile. But perhaps the most influential formulation of this idea in the European tradition is Hegel's. I think it best to construe Hegel's argument as metaphysical rather than conceptual, so I want to begin by first getting the conceptual argument out of the way. If Mouffe's $(1993,84)$ claim that "every definition of a 'we' implies the delimitation of a 'frontier' and the designation of a "them" is to be understood conceptually, and if the terms "we" and "them" refer to human beings, then the problem with Mouffe's argument is that its premise is false. ${ }^{9}$ We can see the falsity of the premise by simply providing, pace the conceptual argument, a definition of a human "we" that does not designate a human "them." Definition: Let $x$ refer to all human beings. There is nothing incoherent about this. Now it might be objected that the definition of "we" in terms of humanity begs the question because it includes a reference to "humans," which is precisely what is in question. This would be to miss the point. The rather simple point is that whatever the definition of "human being," there is nothing incoherent about defining "we" such that it includes all the individuals picked out by the definition. Alternatively, it might be objected that the truth of particularism is demonstrated by the fact that even a universal human "we" presupposes a nonhuman "them." And indeed it does, but this has no bearing on the specific particularist thesis that human collective identities presuppose other human collective identities. In fact, the conceptual argument cannot even motivate drawing the line at human beings: that a universal human "we" presupposes a nonhuman "them" is a function of the qualifier human in "universal human we," not a function of we. There is nothing conceptually incoherent about an identification that goes beyond humanity, to include, for example, all sentient beings. Indeed-Eurocentric humanist intuitions notwithstanding - there is nothing conceptually incoherent about an identification with the entire existing universe, such as that espoused by some pantheists.

Much more interesting for particularists is Hegel's (1977) argument. The premise of his argument is that selfhood involves the desire for self-certainty, that the self has a fundamental desire for self-consciousness and self-worth. The self first attempts to achieve selfcertainty through the appropriation of external physical objects in the world, by asserting dominion over them and integrating them into its plans and projects. But since inanimate objects can only reflect back to the self an image that the self already has of itself, and not the self-certainty it seeks, the satisfaction taken in external objects simply leads to new desires for new objects.

\footnotetext{
9 Though the words "definition" and "implies" here could suggest a conceptual reading, Mouffe's statement can alternatively be read as a metaphysical claim, and in other contexts, which I treat in the final section, she does indeed advance the particularist thesis in metaphysical terms. That Mouffe (2000) does apply "we" and "them" to human beings is made obvious by the anticosmopolitan thesis she derives from this premise (e.g., chap. 2), by her references to "persons" (e.g., 13) and the use of the second-person animate pronoun to refer to the other (such as "his ideas" and "his right" [Mouffe 1993, 4]), and by her appeals to Carl Schmitt. I provide more detailed exegesis of Mouffe's neo-Schmittianism in the paper's final section.
} 
This ultimately renders the desiring self-consciousness dependent on new objects, unable to establish its own independence. So self-certainty through the appropriation of nonhuman objects is inadequate for a human being's sense of self-worth: self-consciousness needs an object that does not cease to be an object for it, an object capable of reflecting back to the self its own conception of itself as free. Self-consciousness requires recognition by an other who is also a self-consciousnessanother human being. And this recognition must be a mutual recognition, because if the self dominates the other, then the other's recognition will not give the self what it requires, since by dominating the other the self denies to the other the freedom it must have if its recognition is to be worth anything (cf. Wood 1990, 86-92).

Taking a cue from Rousseau and Hegel, Charles Taylor (1994, 32-33) argues that the "close connection between identity and recognition" should be understood in terms of the "fundamentally dialogical character" of human life:

We become full human agents ... through our acquisition of rich human languages of expression ... [learnt] through exchanges with others... The genesis of the human mind is in this sense not monological...but dialogical....We define our identity always in dialogue with, sometimes in struggle against, the things our significant others want to see in us. ${ }^{10}$

Taylor's point is sound. But anticosmopolitan particularists are mistaken to think that either Hegel's or Taylor's argument provides them any support: for the particularist thesis in the anticosmopolitan argument outlined above tacitly assumes that what is true of our individual identities is also true of our collective identities. This assumption is false. The Hegel-Taylor argument shows why (1) an individual is able to attain self-consciousness only in relation to an external other, dialogically. This is because either (1a) to see myself as a self I need to be recognized by an external other I also recognize as a self (Hegel), or (1b) my sense of self is only developed and clarified dialogically with external others (Taylor), or both ([1a] and [1b]). But it does not follow (from either [1a] or [1b]) that (2) the individual can only identify with a collectivity that excludes some set of individuals. True, if (a) we accept the Hegelian account, the recognition necessary to an individual's sense of self-hood must be external, because none of the constituent parts of the individual self would possess the independent agency needed for a normatively relevant act of recognition. If we grant Hegel's view of self-consciousness, then the self's own internal recognition of itself as a self is dependent on external recognition. ${ }^{11}$ But the recognition required by a collective identity can come solely from the (other)

\footnotetext{
10 See also Habermas's (1987) discussion of Mead.

11 My point is not to endorse Hegel's view of self-consciousness, but to show that even if we grant it, the ensuing recognition argument does not apply to collective identity. Poststructuralists might reject the Hegelian view out of hand, arguing that Hegel's argument that individual self-consciousness requires external recognition portrays the subject as a unified self-transparent whole, a reified portrayal that
}

individuals who make up that collectivity-an option that would not analogously be available for the development of individual identity itself. In other words, a collective identity can receive either the external recognition of an external other or the internal recognition of its own constituent parts, and the latter does not necessarily depend on the former. ${ }^{12}$ Similarly, if we reject the Hegelian view of self-consciousness but (b) accept Taylor's less metaphysically demanding view that identity is formed dialogically, then in the case of an individual, dialogue implies an external other with whom dialogue must have been at some point conducted; but in the case of a collectivity, the dialogue might simply take place among its own constituent members. Taylor's argument appeals to the fact that identity formation occurs through a linguistically mediated process of $s o$ cialization. For an individual, socialization requires interaction with external others. But socializing an individual to identify with a collective identity could, rather obviously, simply occur through interaction with individuals who also identify with it. ${ }^{13}$ The point is not that the constituent members who engage in mutual recognition or dialogue must be paradoxically specifiable prior to the constitution of the collective identity; the point is simply that the constitution of the collective identity via recognition or dialogue is not dependent on the existence of excluded individuals. Neither Hegel's nor Taylor's arguments necessarily commit them to the particularist thesis.

In other words, the arguments in defense of the particularist thesis (that only collectivities with an external other can be the basis for identity) suffer from a fallacy of composition. Whether collectivities with an external other are better able to win identification is an empirical question. There are no conceptual or metaphysical grounds for thinking that communities "just are particularistic," as Miller asserts, or that "collective attachments are always affirmed in opposition to others," as Schnapper assumes.

As such, we should also reject Miller's (1989b, 239) assertion that loyalty to the human race is meaningless, because loyalty implies partialism:

loyalty ... means favouring the interests of members of the group at the expense of outsiders in certain circumstances. That is what loyalty means: talk of impersonal loyalty, or loyalty to the human race as a whole, is meaningless. ${ }^{14}$

Again, the argument suffers from not being attentive to the distinction between individual and collective identity. It fails to distinguish between an "other" external

ignores the ostensibly divided, opaque, fluid, and composite nature of agency.

12 For a similar argument, see Wendt 2003, 527. In Hegelian terms, we might say that a collectivity could have an "immediate" (unmittelbar) existence; its ultimate mediacy may be in relation to its own parts. Cf. C. Taylor 1975, 105 .

13 This is why it is perfectly reasonable to agree with the second and third, but not the first, of William Connolly's (1991) claims when he says that "every identity is particular, constructed, and relational" (46)

14 Jaeggi (2001, 290-91) makes a similar claim ("To call for 'international loyalty' would therefore be absurd") and seems to suggest that the same point might apply to "solidarity" as well. 
to the collectivity to which I belong and other individual members of the collectivity to which I belong. True, the latter are not "other" insofar as they belong to the same collectivity to which I do, but they are other insofar as they are not me. Loyalty to the human race could very simply mean sacrificing my own narrow personal interests in favor of the interests of the human race as a whole (as when, for example, I make enormous personal sacrifices to ensure that the Earth's air remains pleasant for everyone to breathe). Furthermore, if humanity is in turn constituted by smaller collectivities, and not just individuals, then if I professed loyalty to the human race, I might very sensibly mean that when the interests of humanity as a whole clash with the more parochial interests of some part of humanity to which I belong, I would favor the interests of humanity. To call this nonsensical by definitional fiat is just thatdefinitional fiat.

\section{THE PECULIAR PARTICULARITY OF NATIONAL SOVEREIGNTY}

None of this is to suggest that there are no forms of collective identity that necessarily presuppose an external other. There very well may be. Indeed, I would like to suggest that the particularist thesis that collective identity, solidarity, or community necessarily presupposes an external other has seemed so self-evidently true to so many, despite being based on a patent fallacy, because our intuitions on this matter have been misled by the modern conceptions of sovereignty and nation. ${ }^{15}$

F. H. Hinsley (1986) has argued that the modern notion of sovereignty developed in tandem with the modern state within the context of two problématiques: the nature of legitimate authority within a political community and the regulation of relations between separate political communities. First, the modern notion of sovereignty came to involve the idea that there is a final and absolute political authority within the political community (26). This is what has come to be called "internal sovereignty," which Hedley Bull $(1977,8)$ defines as "supremacy over all other authorities" within a particular territory and over a particular population (cf. Krasner 1988, 86). But second, the modern notion of sovereignty asserts that no other authority exists outside of the political community (Hinsley 1986, 26). This furnishes the state's "external sovereignty," "by which is meant not supremacy but independence" from "outside authorities" (Bull 1977, 8). As such, via the application of reciprocity, the notion of sovereignty was deployed in practice to regulate interstate relations through the mutual recognition of each other's internal sovereignty over its own territory and population (Hinsley 1986, 158).

As constructivists have noted, this reciprocal recognition has become a constitutive feature of the modern practice and institution of state sovereignty (Ruggie 1993, 162). As Alexander Wendt (1992) once argued,

\footnotetext{
${ }^{15}$ Walker (1993, chap. 8) emphasizes the crucial role of the institution of sovereignty in the constitution of modern identities.
}

Sovereignty is an institution, and so it exists only in virtue of certain intersubjective understandings and expectations; there is no sovereignty without an other.... [Sovereignty involves] a mutual recognition of one another's right to exercise exclusive political authority within territorial limits. (412, my emphasis) $)^{16}$

If this is right, then at least state sovereignty would follow a particularist logic of external mutual recognition. (Indeed, this is Hegel's view). ${ }^{17}$ The implication would be that collective identities centered on the modern sovereign state presuppose an external other.

And there is a sense in which this is right. The meaning that sovereignty has acquired for us is, in part, constituted by its role in the Westphalian era of regulating interstate relations. This explains why Anthony Giddens $(1987,281)$ puts the matter in conceptual terms: sovereignty, he claims, "only has meaning in the context of a reflexively regulated system larger than any one state." So if sovereignty has come to mean two things conjoined, that is, internal sovereignty and the reciprocal recognition of this internal sovereignty among states, then sovereignty has come to be defined in a way that conceptually presupposes more than one sovereign power. But the combination of "internal sovereignty" with "external sovereignty" is itself a contingent, historical, not conceptually necessary, development. ${ }^{18}$ The modern ideology of state sovereignty is so pervasive, of course, that the contrary assumption, that internal sovereignty somehow entails external sovereignty, is almost as widely held as the particularist thesis itself (e.g., Philpott 1995, 357). But to say that there is, in the political community, a final political authority requires conceptually that there not be others outside of the political community who can override that authority; it does not require conceptually that there be others outside of the political community who cannot override that authority. Sovereignty has come to mean, for us, both internal and external sovereignty, precisely because it has been deployed in the Westphalian era as a principle of legitimation regulating interstate relations. ${ }^{19}$ But a "world sovereign," sovereign in the sense of being an ultimate political authority, is not conceptually incoherent; it would simply strip sovereignty of the additional meaning it has for us as an institutionalized way of regulating interstate relations. Indeed, Claude Lefort $(2000,33)$ argues that in France the innovation of the Middle Ages was precisely the delimitation of sovereignty: inscribing sovereignty on a limited, bounded territory in formulae such as "empereur dans son royaume" was initially deeply paradoxical, for such formulae combine "the idea of imperium [previously] reserved for the

\footnotetext{
16 Wendt $(1999$, chap. $5 ; 2003)$ qualifies this view significantly in later work

${ }^{17}$ See Hegel 1991, paragraphs 321-324, 331, plus remarks, and Brown's $(2001,129)$ reconstruction of the argument.

${ }^{18}$ Spruyt (1994) argues that the sovereign territorial state, with a hierarchical internal authority structure and a demarcated territorial jurisdiction, prevailed over other modes of political organization because of its capacity to prevent free-riding domestically and to make credible commitments externally.

${ }^{19}$ Never perfectly, of course. On this, see Krasner 1995.
} 
Sovereign of the world with that of a power exercised within the limits of a country."

As Stephen Krasner (1999, 3-4) points out, the different senses of sovereignty both are conceptually independent and have been routinely disaggregated in practice. Indeed, the two components can be disaggregated further: for Krasner, there are four "meanings of sovereignty." (1) The claim to legitimate authority and effective control within a territorially circumscribed polity (what Krasner calls "domestic sovereignty") is distinct from (2) the capacity to regulate movement across the circumscribed borders ("interdependence sovereignty"). Even (3) "the exclusion of external actors from authority structures within a given territory," which he calls "Westphalian sovereignty," is distinct from (4) what he calls "international legal sovereignty," or "practices associated with mutual recognition" between territorial entities with formal judicial independence. Krasner demonstrates not only that, in practice, states have possessed sovereignty in each of these senses without the others, but that in some cases the possession of one kind of sovereignty can actually undermine another. It is only sovereignty in the sense of international legal sovereignty that conceptually presupposes recognition by another sovereign. Sovereignty in the sense of border control requires an other, but not necessarily another sovereign-just other territory. And Krasner's "domestic sovereignty" and "Westphalian sovereignty" do not conceptually presuppose the existence of an external other at all.

Despite the fact that, in practice, states have possessed the various kinds of sovereignty in different combinations and degrees, the modern ideology of sovereignty nevertheless combines all four senses and construes them as mutually entailing. ${ }^{20}$ Given this (historically contingent) combination - given what sovereignty has come to mean ideologically-any collective identity that is linked to this modern notion is no doubt prone to reproduce its requirement of external recognition. This is not to say, of course, that alternative ideologies of (say, divided or dispersed) sovereignty have been completely crushed-far from it. The point is, rather, that the ideological combination of these distinct attributes has powerfully shaped the terms of the debate.

So it is rather unsurprising that national identity has come to be conceived in this way as well. After all, a typical feature of the modern phenomenon of the nation is the political claim to sovereignty over some territorially defined space. ${ }^{21}$ Benedict Anderson (1991, 6 ) defines the nation as "an imagined political community" that is "imagined as both inherently limited and sovereign." Since the modern ideology of sovereignty construes the sovereign as necessarily one sovereign among others, to say that the nation is imagined as

\footnotetext{
${ }^{20}$ This modern ideology has been powerfully shaped by the Hobbesian/Rousseauist theory of the indivisibility of sovereignty, directed against the Grotian/Pufendorfian theory of the parts of sovereignty. See Derathé 1970, 280-94.

${ }^{21}$ Lefort $(2000,31)$ remarks that without this link to sovereignty, "le terme ne désignerait qu'une ethnie."
}

sovereign is already to have said that it is imagined as limited. So it is no surprise that national identity as we know it today is, like the modern notion of sovereignty, necessarily particularist. Jonathan Rée $(1998,83)$ has even argued that identification with a nation presupposes the existence of other nations:

\begin{abstract}
You cannot have a sense of belonging to the same nation as your neighbors unless you are aware of it as one nation among others and of an imagined totality of nations. ... Nations exists only in the plural, in other words, and if every nation but one were supposed destroyed, then the last one would cease to be a nation as well. Local sentiments acquire national significance only in the light of an imagined international order.
\end{abstract}

Rée's argument is that to transform local sentiments of attachment, which find their sources in the personal experiences of face-to-face interaction, into the necessarily imagined realm of the nation, one must imagine one's nation as bounded and in contrast to other nations, because of the notion's embeddedness in an imagined international order. But contrary to what the particularist might suggest, this does not establish that individuals can come to identify with an imagined, non-face-to-face community only if that community is particular and bounded. Rather, the point must remain specific to national identity: identification with the nation, as opposed to just any form of imagined community, presupposes the existence of other nations. What the particularist thesis falsely claims for collective identity as such might be true of some collective identities.

To sum up, then: even the apparently necessary particularism of national identity depends on the nation having become invested in the modern notion of sovereignty. With the rise of the idea that sovereignty inheres in the nation, if the nation just is, by definition, a community that is imagined as sovereign, and if sovereignty refers to an institutionalized way of regulating external relations with other sovereigns, then national identity is necessarily particularistic. Again, this concatenation of ideas is historically contingent. Liah Greenfeld (1992, 8-14, passim) has in fact argued that the conception of the nation as a particular community, i.e., one whose uniqueness requires a contrast with other nations, is a late, eighteenth-century, development. If she is correct, then it is no surprise that this development coincides with the rise of the doctrine of national sovereignty.

\section{SCHMITT: THE POLITICAL ENEMY ARGUMENT}

Does any of this show that a collective identity centered on "humanity" could in principle be the basis for a democratically legitimated cosmopolitan political order? Such a conclusion might still be denied by urging that, even if collective identities as such need not presuppose an other, specifically political collective identities do. This is the thrust of Mouffe's (2000, 4344) Schmittian claim that humanity "is not a political concept"; it is also what motivates her endorsement of 
Schmitt's conclusion that "political democracy cannot be based on the generality of all mankind" (Mouffe 2000, 40). Indeed, the reach of the Schmittian objection is not restricted to specifically cosmopolitan projects: the objection, if valid, would show that my argument about collective identities has no bearing on the political sphere at all.

What I want to demonstrate is that Carl Schmitt's argument, which centers on an analysis of the nature of sovereignty, the modern state, and "the political" sphere, far from providing a wholly novel justification for the particularist thesis, instead provides a brilliant illustration of how the modern ideology of sovereignty helps to mask the fallacy, already noted, behind the particularist thesis: Schmitt's "political" argument in defense of the particularist thesis, and the anticosmopolitan conclusion he draws from it, mirrors the same fallacious structure of the recognition and dialogic arguments for particularism-it rests on a systematic conflation of the necessity of internal and external "others."

For Schmitt (1996, 19, 47), the modern sovereign state is "a specific entity of the people," "an organized political entity" that seeks to maintain internal peace, is "territorially enclosed," and is "impenetrable to aliens." At least for the early, pre-Nazi Schmitt (1985b), sovereignty inheres, within the context of a Rechtsstaat, in the one who "decides what constitutes an exception" in the application of general rules to particular circumstances (43). ${ }^{22}$ This presupposes, with Jean Bodin, a distinction between laws and exceptional decrees or measures and, thus, between ordinary times and exceptional or emergency situations. ${ }^{23}$ As Schmitt puts it elsewhere, "Sovereign is he who decides on the emergency situation [or exception, or state of emergency (Ausnahmezustand)]" (1922, 8; 1985a, 5). ${ }^{24}$ The nature of political emergency arises, for Schmitt (1996), from the fact that the political sphere is inherently constituted by the distinction "between friend and enemy" (26). "The concept of the state," he asserts, "presupposes the concept of the political" (19) and the political is always haunted by the spectre of existential struggle:

to the enemy concept belongs the ever present possibility (die ihm Bereich des Realen liegende Eventualität) of combat.... The friend, enemy, and combat concepts receive their real meaning precisely because they refer to the real possibility (reale Möglichkeit) of physical killing. (Schmitt 1987, 33; 1996, 32-33)

As Gopal Balakrishnan (2000, 148, 192) points out, Schmitt later abandons the sharp distinction between laws and emergency measures and, by the time he becomes a Nazi, completely jettisons the theoretical apparatus of the Rechtsstaat: the "total" sovereign legit-

\footnotetext{
${ }^{22}$ Cf. Schmitt 1985b, 42: "The whole theory of the Rechtsstaat rests on the contrast between law which is general and already promulgated, universally binding without exception, and valid in principle for all times, and a personal order which varies case to case."

${ }^{23}$ On the early Schmitt's discussion of and debt to Bodin, see Balakrishnan 2000, 34

${ }^{24}$ For discussion of the state of emergency, see Balakrishnan 2000, $44-46$.
}

imately rules by decree. What remains constant, however, is Schmitt's commitment to viewing the sovereign as the one who decides matters of existential struggle. Rechtsstaat or no, sovereignty is a question of who "decides the extreme case (Konfliktsfall) and determines the decisive friend-and-enemy grouping" (Schmitt 1987, 43; 1996, 43).

Schmitt's (1996) anticosmopolitan conclusion derives from an argument whose structure is similar to the anticosmopolitan argument I considered earlier, though it begins with a stronger premise:

The political entity presupposes the real existence of the enemy and therefore an other, coexisting, political entity. As long as a state exists, there will thus always be in the world more than just one state. A world state which embraces the entire globe and all of humanity cannot exist. The political world is a pluriverse, not a universe. (53)

Schmitt thus introduces two modifications to the anticosmopolitan argument. First, he glosses the particularist thesis in its stronger, adversarial form. Second, he embeds the particularist thesis within a specifically "political" context. Schmitt's political version of the anticosmopolitan argument can be reconstructed as follows.

1. Any political entity presupposes an adversary.

2. An entity's adversary is other than the entity itself (i.e., it is an other to the entity).

3. Therefore, any political entity presupposes an adversary who is its other.

4. The sovereign state is a political entity.

5. Therefore, the sovereign state presupposes an other (another sovereign state who is its adversary).

6. Therefore, a sovereign global state is impossible.

Premise 1 is a political version of the adversary claim and Premise 2 reflects the exclusion claim. Thesis 6 is Schmitt's version of the anticosmopolitan thesis. Steps 1-5 constitute Schmitt's argument for his political and adversarial version of the particularist thesis (Thesis 5), construed in terms of sovereignty. I take Premise 1 for granted for now in order to notice the (fallacious) structure of Schmitt's argument for his version of the particularist thesis. My thesis is that by embedding the particularist thesis within an argument framed in terms of sovereignty, Schmitt helps himself to an equivocation between the internal and external aspects of sovereignty; in other words, the argument conflates internal and external "others."

More particularly, the derivation of Thesis 5 (that the state presupposes an other state) depends on an equivocation between two senses of "political entity" and/or between two senses of "other." "Political entity" can refer to the state as a whole, that is, the entire population, territory, institutions, etc., within its bounded spacecall this the comprehensive sense of political entity. Or it can refer to a component part of the state, for example, the sovereign power within it-call this the partial sense. Similarly, an entity's “other" can refer to another entity that shares no constituent parts with itcall this the external (or strict) sense of "other." (This 
is the sense in which I have used the word so far.) Or it might refer to another entity whose constituent parts are not fully coterminous with it, i.e., an entity that is not identical to it - call this the expansive sense of "other." So defined, the external (or strict) sense of other is a species of the expansive sense. One example of a given political entity's other in the expansive but not strict sense might be another political entity some and only some of whose citizens (or territory, institutions, etc.) are shared with it: for example, England and Scotland share some citizens and institutions (the British Parliament) but not others (the Scottish Parliament). Call this an overlapping other. Another kind of other in the expansive, nonstrict sense is one that is simply a part of the first entity: call this the encompassed sense of other. For example, Scotland is Great Britain's encompassed other. The converse would be the encompassing sense of other.

The plausibility of Thesis 2 (that an entity's adversary is other than itself) depends on construing "other" in the expansive sense; the restrictive external sense of "other" would implausibly rule out the possibility that the adversarial relation is between an entity and one of its constituent parts. Canada's "adversary" may be Russia (its external other) or, as arguably often is the case, it may be Quebec (its encompassed other). But once "other" in Thesis 2 is understood in this expansive sense, if Thesis 3 is to be derived from Theses 1 and 2, then it must also be understood as leaving open the possibility that the adversary is an internal adversary, i.e., a constituent part of the political entity, an "other" in the encompassed sense. Hence the only way to construe, in Thesis 3, "other" in the strict, external sense is to assert it independently of Theses 1 and 2. But even if it is so asserted, then my point can be made in a different way: if "other" is construed in the sense of external other, then Thesis 3 is plausible only if "political entity" is understood in the partial (and not comprehensive) sense-as the part of the state that is sovereign, for example. For the sovereign's adversary, as Schmitt knew perfectly well, could be a domestic enemy. ${ }^{25}$

The upshot is that Thesis 3 (that any political entity presupposes an adversary who is its other) only makes sense on one of two assumptions: either "other" is to be understood in the expansive sense or "political entity" is to be understood in the partial sense (or both). The problem is that in neither case can Thesis 5 be logically derived from the premises. For the derivation of Thesis 5 from Theses 3 and 4 either requires construing "other" expansively, in which case its claim that "the sovereign state presupposes an other" can refer to an encompassed other-for example, a part of the state who is not sovereign-or "sovereign state" (in Thesis 4) must be equated with the partial sense of political entity, as not referring to the entire state, in which case its strict other may be a nonsovereign within the political entity. The outcome in both cases is the

25 "As long as the state is a political entity this requirement for internal peace compels it in critical situations to decide also upon the domestic enemy (innern Feind)" (Schmitt 1996, 46; 1987, 46). same, and in neither case does it follow that, as Thesis 5 claims, the sovereign state presupposes another sovereign state. A sovereign state simply presupposes something over which it is sovereign. So even if "the political" depends on the friend-enemy distinction, it does not follow that a sovereign state's enemy must be other territorially organized states. That state violence is always a present possibility, in other words, does not imply the existence of "others" external to the jurisdiction of the legitimated use of violence.

The fallacious structure of the Schmittian political enemy argument for the particularist thesis mimics, of course, the structure of appeals to the recognition or dialogic arguments: while the latter appeals fail to see that a collective identity can be "recognized" both by an external "other" in the strict sense and by its own constituent parts, the Schmittian argument fails to see that a sovereign state may find an adversary both in an "other" state (i.e., an external other) and domestically. The role that "sovereignty" plays here in masking this equivocation between the strict and expansive senses of "other" is rather clear: the point is that Schmitt's argument in The Concept of the Political rests on a systematic conflation of internal and external sovereignty-which of course he believes go together.

The upshot of my critique as it stands, however, is rather grim for the cosmopolitan thesis that Thesis 6 opposes: I have refuted the derivation of Thesis 6 by arguing that the adversary-by which Schmitt means enemy-of the sovereign state may be an internal adversary. And a Schmittian might be willing to concede this: as Balakrishnan $(2000,110)$ points out, at the time of writing The Concept of the Political in the 1930s, there

were two, equally compelling modern conceptions of the fundamental axis of political division: one which saw history as the history of class struggles; and another which saw nation-states as the subjects of all world-historical conflict. Although Schmitt was closer to the latter conception, he never dismissed the plausibility of the former.

So in principle the enemy may be an external enemy (other nation-states) or it may be an internal enemy (the proletariat or the capitalists), and "the question of which of these two conceptions was the politically decisive one could be determined only historically" (Balakrishnan 2000, 110-11). ${ }^{26}$ But if indeed a political entity presupposes an adversary, then it appears that a cosmopolitan political order taking the form of a world state could be erected only on the backs of internal enemies whom the state dominates and seeks to crush. ${ }^{27}$ A world state would be a world domination of one part

\footnotetext{
${ }^{26}$ On Schmitt's equivocation over whether the enemy must be an external enemy or a domestic enemy, see Derrida 1994, esp. 14042. See also the related equivocation that Derrida notes between Schmitt's external/domestic distinction and public/private distinction $(1994,111)$.

27 Cf. Schmitt 1996, 51: "The solemn declaration of outlawing war does not abolish the friend-enemy distinction, but, on the contrary, opens new possibilities by giving an international hostis declaration new content and new vigor."
} 
over another-a worldwide dictatorship of the proletariat, for instance. The world state would be-to raise the old bogeyman once again - a terrifying nightmare. And if not a world state, then a cosmopolitan order would be an imperialist order à la the British Empire, imposed by a world hegemon who dominates and lords over its "domestic" adversaries. A cosmopolitan order perhaps, but not a democratically legitimated one.

The grim conclusion depends, of course, on taking Premise 1 (that any political entity presupposes an adversary) for granted. And this premise is the adversary claim that forms the second component of the stronger version of the particularist thesis. So if we expand the term "entity" to encompass collective identities, and if we assume that the adversary must be an external adversary, then Premise 1 itself turns into a strong and politicized version of the particularist thesis: a collective political identity requires not just an external other, but an external adversary. The implication is that my critique of the particularist thesis is politically irrelevant. This is the point of saying that humanity is not a political concept. By contrast, if we assume that the adversary can be an internal adversary, then Premise 1 yields the conclusion that any appeal to "humanity" as a collective identity can work politically only insofar as it serves to legitimate and mask the domination of one part of humanity over others in the false name of humanity itself. (This is how Schmitt suggested "humanity" is in fact used.) ${ }^{28} \mathrm{~A}$ "solidarity" centered on such an identity could hardly play the required role in democratic legitimation, for it would be an oppressive, hierarchical identity serving to crush some who are at one and the same time humanity's "members" and lorded over by their "fellows." We are talking about an imperialist sort of cosmopolitan "solidarity" à la the white man's burden.

So Premise 1 seems to imply either (A) that there can be no politically relevant collective identity at the global level-a political version of the particularist thesis-or (B) that such an identity would be terribly oppressive. Neither option allows for a democratically legitimated cosmopolitan political order based on a genuine sense of human solidarity.

The question is why we should grant Premise 1 in the first place. Of course if we define "the political" in particularist or adversarial terms as Schmitt does-if the political presupposes by definition a distinction between "friend and enemy" - then it is hardly surprising if "political" collective identities are necessarily particularistic or oppressive. But to glean a substantive argument requires that we abandon the tautological helps. Schmitt's stated motivation for defining the political in these terms is to provide a definition independent of the state: first, in order to avoid the circularity of defining the political and the state in terms of each other and, second, in order to acknowledge the possibly

\footnotetext{
28 "When a state fights its political enemy in the name of humanity, it is not a war for the sake of humanity, but a war wherein a particular state seeks to usurp a universal concept against its military opponent" (Schmitt 1996, 54.) Schmitt's comment is specifically about interstate war, but his point about the function of "humanity" is general.
}

political dimension of society (Schmitt 1996, 20-22; cf. Balakrishnan 2000,103). With Schmitt's goal in mindto determine the relation among the political realm, modern state, and society-the political and the state should indeed not be defined in terms of each other; but with our goal in mind-to determine the relation among the political realm and the particularist thesis and the adversary claim - then the political should not be defined in terms of the particularist thesis or adversary claim. It is, as G. E. Moore might have said, always an "open question" whether the political is particularist or adversarial, and not something that can be settled by definitional fiat.

Schmitt's substantive argument for the decisiveness of the friend/enemy distinction, and thus for the adversary claim that every political collectivity must be constituted antagonistically in relation to an other (whether external or domestic), is Hobbesian: Schmitt (1996) appeals to the ineradicable possibility of existential struggle to the death, "the real possibility of physical killing" (33). This possibility of killing necessarily insinuates itself into the very nature of politically constituted collectivities: the possibility of war constitutes a collective political entity essentially as a combative collectivity, a "kämpfende Gesamtheit von Menschen.'

The question is why one possibility among othersand a possibility is always only one among others - should be determinative for political relations. Jacques Derrida (1994, 105-6) has argued that in seeing the possibility of an event as essentially constitutive of the political, Schmitt is forced to portray the possibility as an event itself. Schmitt's language constantly betrays this "slide from possibility to eventuality ... and from eventuality to effectivity": 29

As soon as war is possible, it is presently in process, he seems to say... whether it be declared or not... war takes place, it has already begun before beginning, as soon as it is held for eventual.... And it is eventual as soon as it is possible.... Here he invokes eventuality (wenigstens eventuell), there he invokes possibility (Möglichkeit).... As soon as war is possible/eventual, the enemy is present, he is there, his possibility is presently, effectively supposed and structuring.

It might be replied, on Schmitt's behalf, that not all possibilities are equal, that some possibilities do indeed structure reality, and that killing is one of these structuring possibilities. We can get a sense of the kind

\footnotetext{
${ }^{29}$ Schmitt (1987) writes, for instance, that "the enemy exists only with an at least potentially-i.e. the real possibility of afighting collectivity of people confronting a similar collectivity" [Feind ist nur eine wenigstens eventuell, d.h. der realen Möglichkeit nach kämpfende Gesamtheit von Menschen, die einer ebensolchen Gesamtheit gegenübersteht] (29, my translation). The published English translation ("An enemy exists only when, at least potentially, one fighting collectivity of people confronts a similar collectivity" [Schmitt 1996, 28]) is more elegant, but by collapsing the wenigstens eventuell, d.h. der realen Möglichkeit into "at least potentially," it misses the nuances in the original relevant to Derrida's argument. As Derrida $(1994,106)$ points out, Schmitt's French translator fails to mark the difference between wenigstens eventuell and Möglichkeit as well.
} 
of argument required to transform mere possibility into effectivity by returning to the Hobbesian roots of Schmitt's argument. In order to show that the possibility of killing necessarily leads to war in the state of nature, Hobbes's ([1651] 1996) argument requires at least three premises. (a) First, Hobbes assumes that by nature human beings' overwhelming motive for action is self-preservation. (b) Second, Hobbes assumes the truth of epistemological skepticism vis-à-vis the external world. The consequent epistemological uncertainty implies that, in the state of nature, we simply cannot know whether the other whom we confront is benign or a threat to our survival (and the latter is always a possibility). (c) Third, Hobbes structurally defines the state of nature as a state where there is no overriding common sovereign power who can guarantee one's security against potential aggressors (through the enforcement of common rules). Hobbes's conclusion is that (a) the motive for self-preservation, combined with (b) our epistemological weakness and (c) structural lack of sovereign power, renders each of us "diffident" and thus prone to engage in preemptive strikes. This, then, is how the possibility of killing infallibly transforms itself into a reality for Hobbes. ${ }^{30}$

The problem for Schmitt is twofold. First, the conclusion does not quite follow from the premises: when confronted with an other being, my epistemological weakness in fact faces three logical possibilities, not two. The other may be benign, or a threat to my survival, but for all I know the other might also be a willing and cooperative aid to my survival-indeed, his or her benevolence may turn out to be indispensable to it. So it is not clear why epistemological uncertainty should not lead to hope, rather than diffidence. This is presumably why Hobbes adds another assumption about human nature to get humans on a war footing: he needs to assert that (d) by nature humans seek glory. The second problem for Schmitt is that once we abandon any of the four premises, Hobbes's conclusion does not follow. To say nothing of Hobbes's assumptions about human nature, and the skepticism that Schmitt does not share, the structural assumption (c) that Hobbes needs to make demonstrates the way in which the effectiveness or realization of a possibility is dependent on contingent features of empirical reality.

In other words, in order to construe the possibility of killing as an eventuality, if not inevitability, we need to engage in two reifications. First, we must explain human behavior in terms of question-begging assertions about human nature. Such assertions, if themselves based on observations of human behavior or psychology, are question-begging because, as Rousseau famously pointed out in his second Discours, the characteristics we attribute to human nature may be the effect, not

\footnotetext{
${ }^{30}$ Hobbes ([1651] 1996) gives a succinct statement of his argument, which moves from the possibility of killing to the incentives for preemptive strikes and the inevitability of the state of war in the state of nature (87-89). On Hobbes's motivational assumption of self-preservation (as opposed to the more widely attributed motive of self-interest) and on his epistemological skepticism, see Tuck 1989 and Tuck's introduction in Hobbes (1651) 1996.
}

the cause, of sociopolitical phenomena. ${ }^{31}$ Second, we would need to take for granted precisely those contingent structural features of reality that should be the object of empirical investigation. By transforming a contingent, empirical possibility into a metaphysically determinative necessity, Schmitt has simply reified the contingent causes of antagonism. Not only does such reification illegitimately constrain normative theory by confronting it with fake metaphysical barriers, it also hampers the development of realistic empirical theories seeking to explain the contingent causes of antagonism and war. The question of when and under what circumstances the possibility of existential struggle is transformed into actual combat, or even relations of antagonism, is an empirical one. ${ }^{32}$

\section{MOUFFE: THE DERRIDEAN DIFFERENCE ARGUMENT}

Chantal Mouffe provides a more promising argument for the political version of the particularist thesis and adversary claim espoused by Schmitt. She argues that (a) "any social objectivity is constituted through acts of power" and (b) "has to show the traces of the acts of exclusion which govern its constitution" (Mouffe 2000, 21). The point applies to a collective identity insofar as it has "objective" social existence, i.e., insofar as it manifests itself in social effects. Elsewhere Mouffe makes what is apparently a related point: " $\left[\mathrm{a}^{\prime}\right]$ Politics aims at the creation of unity in a context of conflict and diversity; $\left[b^{\prime}\right]$ it is always concerned with the creation of an 'us' by the determination of a "them"' (101). The point seems to be that $\left(a^{\prime}\right)$ in the face of conflict, (a) collective identities are able to unify individuals only via the exercise of power. And (b) this exercise of power itself necessarily does "violence" to (some?) individuals, for such power can never be fully subject to rational justification. As such, from any given forged unity a remainder of exclusionary violence inevitably escapes: "the impossibility of establishing a rational consensus without exclusion" (45) follows from the fact that "difference is the condition of the possibility of constituting unity and totality at the same time that it provides their essential limits" (33). The upshot is, apparently, that $\left(b^{\prime}\right)$ every collective identity simultaneously and necessarily excludes some individuals from its constitution.

I find the points that Mouffe makes in (a), (b), and $\left(a^{\prime}\right)$ quite plausible. The problem lies with $\left(b^{\prime}\right)$, the upshot. I see two ways of reading this upshot.

(A) The first way assumes that the "them" required in the construction of "us" refers (1) to actually existing particular individuals who are (2) denied membership. It assumes, in other words, that Mouffe is a

\footnotetext{
31 That Schmitt reifies the possibility of existential struggle in terms of human nature is certain: it is precisely this possibility of existential struggle to which Schmitt (1996) is referring when he asserts that "all genuine political theories presuppose man to be evil, i.e., by no means an unproblematic but dangerous and dynamic being" (61).

${ }^{32}$ For a similar argument applied to state behavior in international relations, see Wendt 1992.
} 
neo-Schmittian seeking to defend Schmitt's version of the particularist thesis.

That Mouffe does indeed subscribe to Schmitt's position here is clear. She explicitly follows Schmitt in claiming that antagonism "is inherent to all human relations," that this antagonism is the defining feature of "the political" (Mouffe 2000,101), and that the process of collective identity formation can only be understood in light of this fact:

In the domain of collective identifications, where what is in question is the creation of a 'we' by the delimitation of a 'them', the possibility always exists that this we/them relation will turn into a relation of the friend/enemy type. (Mouffe 1993, 2-3).

While here Mouffe (1993) suggests that the enemyrelation is a possibility, elsewhere she claims that it is in fact a necessity: "to construct the 'we' it must be distinguished from the 'them', and that means establishing a frontier, defining an 'enemy"' (69). Mouffe's argument, in other words, reproduces precisely the same equivocation we have already seen in Schmitt. And lest there be any doubt that the "enemy" whom Mouffe considers necessary for collective identity formation refers to concrete, actually existing human beings, she notes that "it is useful to remember with Carl Schmitt that the defining feature of politics is struggle and that 'There always are concrete human groupings which fight other concrete human groups..." (113; quoting Schmitt 1985b, 67). She does, however, make one modification to Schmitt's use of the term "enemy." She distinguishes between two kinds of enemy: an enemy proper, whom one antagonistically seeks to destroy, and what she calls an "adversary," which is an enemy whom one agonistically combats but whose existence is deemed legitimate (Mouffe 1993, 4).

The novelty of democratic politics is not the overcoming of this us/them opposition-which is impossible-but the different way in which it is established ... the aim of democratic politics is to construct the 'them' in such a way that it is no longer perceived as an enemy to be destroyed, but as an 'adversary'. (Mouffe 2000, 101-2, my emphasis)

The fact that an enemy can take the form of a legitimate adversary makes democracy possible; but the fact that it is "impossible" to form collective identity except in relation to a concrete other qua enemy makes cosmopolitan democracy impossible: Schmitt "is right to say that a political democracy cannot be based on the generality of all mankind, and that it must belong to a specific people" (Mouffe 2000, 40).

If $\left(b^{\prime}\right)$ is read in this light, then Mouffe is advancing the Schmittian particularist thesis: the enemy necessary for collective identity formation must be an external other consisting of concrete individuals excluded from membership. This would explain why democracy belongs, as Mouffe says, to a "specific"-i.e., particularpeople. $^{33}$

\footnotetext{
${ }^{33}$ Cf. Mouffe 2000, 4: "As my discussion of Carl Schmitt's theses... makes clear, democratic logics always entail drawing a frontier between 'us' and 'them', those who belong to the 'demos' and those who are outside it."
}

If this is the correct reading, then my point is simply that conclusion $\left(b^{\prime}\right)$ does not follow from Mouffe's argument. Some might, for example, be sympathetic to (a), (b), and ( $\left.a^{\prime}\right)$ for the reasons that Paul Ricoeur gives for what he calls the "tragedy of all human action": beginning with the pluralist premise that there exist a plurality of incommensurable ends-which implies that "the historical realization of one value cannot be secured without harm to some other value"-he concludes that "in action, one must choose, hence prioritize, hence exclude." The upshot, for Ricoeur, is that every constitution involves exclusion, which consists in the compromise of some binding values in order to secure others. ${ }^{34}$ Now, one might argue in defense of Mouffe that "exclusion," whether of the value-conflict sort Ricoeur has in mind or not, will invariably be targeted at particular individuals. And this may be true; but exclusion need not consist in the denial of membership to particular individuals, which is what the particularist thesis claims. The exclusionary violence to which Mouffe refers in (b) might, for example, take the form of including the targeted individuals as members by forcibly excluding (i.e., eliminating, suppressing, privatizing, reeducating, etc.) characteristics that fail to fit into the mold-the way that non-Parisians in France were included and assimilated into the French nation, for instance (Weber 1976). (Yes this occurred against the backdrop of "Spaniards" and others who were not members; my point is simply to illustrate what I mean by "exclusion" in nonmembership terms.) The Schmittian particularist thesis does not follow from Mouffe's argument.

(B) Of course it might be replied that if every forging of a unity inevitably produces exclusions, individual targets of exclusions are effectively denied full membership, even if formally included: some ostensible "members" invariably must be incarcerated, socially marginalized, or perhaps simply misrecognized. This glosses Schmitt's Premise 1 (that every political entity presupposes an enemy) in terms of domestic oppression, and it provides the second way of reading the upshot $\left(b^{\prime}\right)$ of Mouffe's argument. While the first reading assumed that the enemy Mouffe deems necessary for collective identity formation must be an external other consisting of concrete individuals excluded from membership, the second reading assumes that the enemy can also be an enemy internal to the collective itself. We have already sighted this spectre of a domestic enemy in Schmitt's work; on this reading, collective identity presupposes an other, but it is an other in the expansive sense of the term.

What is common to both the strict and the expansive readings of Schmitt and Mouffe, however, is that the enemy is supposed to consist in an empirically specifiable group(s) of actually existing concrete individuals. And therein lies the problem. We can begin to see

\footnotetext{
34 "Dans l'action, il faut choisir, donc préférer, donc exclure... chaque constitution exprime une échelle de priorités irréductibles l'une à l'autre en vertu de raisons contingentes, tributaires d'une conjoncture géographique, historique, sociale et culturelle, non transparente aux agents politiques du moment" (Ricoeur 1991, 169-70).
} 
the problem by turning to Mouffe's more explicit argument for the adversary claim and the necessity of the other-relation (whether in the strict or expansive sense). Mouffe seeks to defend her Schmittian conclusions by appeal to an intellectual tradition whose point of departure is not Schmitt, but Derrida's engagement with Saussure and Nietzsche: she appeals to the related Derridean categories of "difference" and the "constitutive outside."

Derrida's (1967, chap. 2) notion of the constitutive outside emerges in the context of his critique of structuralist linguistics. Mouffe has sought to generalize Derrida's argument about language to identity formation, and she is not the only one to read Derrida in this way (e.g., Wenman 2003, 60; cf. Laclau 1996). What is particular to Mouffe is the argument that "the notion of the 'constitutive outside', borrowed from Derrida, can help us elucidate" her explicitly Schmittian theses. "One of Derrida's central ideas," Mouffe (1993) claims,

is that the constitution of an identity is always based on excluding something and establishing a violent hierarchy between the resultant two poles... This reveals that there is no identity that is ... not constructed as difference, and that any social-objectivity is constituted through acts of power. It means that any social objectivity is ultimately political and has to show traces of the exclusion which governs its constitution. (141)

Thus the notion of the constitutive outside helps explicate

the antagonism inherent in all objectivity and the centrality of the us/them distinction in the constitution of collective political identities. This arises when this us/them relation, which until then was only perceived as simple difference, began to be seen as one between friend and enemy. From that moment on ... it becomes political (in Schmitt's sense of the term). (Mouffe 2000, 13)

The constitutive outside is supposed to map onto the "them" that Mouffe thinks is constitutively necessary for a collective "we," which in turn supposedly maps onto the Schmittian friend/enemy relation. The move from Derrida to Schmitt requires four steps: (1) identity presupposes difference, which means that difference is constitutive of identity; (2) therefore, any identity constitutively presupposes an other different from it; (3) this relation to an identity's constitutive other is inherently characterized by antagonism; and (4) in the case of collective identity formation, the categories of "identity" and "other" map onto sets of actually existing concrete individuals, viz., friend and enemy. I have already discussed Derrida's critique of the conflation of possibility and eventuality (and the reification of the causes of antagonism) involved in the Schmittian adversary claim contained in step (3). Here I focus on step (4), which is wholly incompatible with the Derridean argument about difference.

To see this, we need to attend to the specifics of Derrida's argument. Derrida's (1967, chap. 2) wellknown thesis is that the "inside" of a supposedly closed conventional linguistic structure-what in Saussure's structuralist linguistics is called a langue - presupposes an "outside" that both is necessary for the closure of the linguistic structure and makes closure impossible. For Saussure (1960), a sign consists in the relation between a concept (signifié) and an acoustic image (signifiant). Saussure argued that the relation between a signifie and a signifiant with which it is associated in a linguistic structure is arbitrary and is wholly determined (as a matter of convention) by the sign's position within the totality of the linguistic structure. Meaning, therefore, does not derive from the relation of an atomistic sign to a nonlinguistic entity (such as a mental state or external object); rather, a sign derives its meaning solely from its relation to (and difference from) all the other signs within the totality of the linguistic structure itself. ${ }^{35}$ For structuralist linguistics, then, the wholeness of a langue, and its wholly closed character, is necessary to explain both how the sign relation can be arbitrary and how the communication of linguistic meaning is nonetheless possible. Derrida (1967) has argued that this closure of the linguistic system, on which structuralist meaning depends, conceptually and so constitutively requires drawing a boundary around the langue, i.e., the delimitation of what is interior from what is exterior to it (49$53,65-66)$. The problem is, according to Derrida, that such closure, and the determination of an outsideboth of which are necessary for meaning - would also make meaning impossible. Within such a closed system, since each sign must be defined in relation to the totality of other signs within the same linguistic structure, its meaning is subject to a vicious circularity: if the meaning of sign $a$ is given by its difference from $b$ (etc.), and the meaning of $b$ (etc.) is in turn given by its difference from $a$, then the meaning of $a$ is ultimately dependent on the meaning of $a$ itself, which is precisely what is in question. While the location of each sign within the structure of relations is fixed, its meaning would remain empty of content because ultimately self-referential. ${ }^{36}$ Hence the need to refer to something outside of the linguistic structure. Thus the "outside" of a linguistic structure is constitutive of a langue in two (contradictory) ways: first, this outside is required to constitute the boundaries that give closure to the totality of the linguistic structure; second, this outside must penetrate that structure in order for meaning to be possible in the face of a vicious, self-referential circle. This requires the signification of something outside of the putatively closed system of signification. That what is supposedly "outside" is actually constitutive of the "inside" in this way fatally calls into question, according to the

\footnotetext{
35 As Talbot Taylor $(1992,85)$ notes, "As a system of signs langue consists in the matching not of individual concepts with individual acoustic images, but of two structured domains: that of concepts differentially defined and that of acoustic images differentially defined." Each signifié, in other words, derives its meaning from its difference with all other signifiés in the linguistic structure, and each signifiant is negatively defined by its contrast with all other signifiants.

${ }^{36}$ As T. Taylor $(1992,166)$ puts it, on Derrida's view, "In order to interpret a sign ... an interpreter must consider those signifiants and signifiés to which that sign's own signifiant and signifié are opposed; but even to identify those signifiants and signifiés she must consider the signifiants and signifiés to which they, in turn, are opposed (and so on ad infinitum)."
} 
Derrida, the distinction between inside and outside, on which structuralist linguistics depends. ${ }^{37}$

The upshot is that, even if Derrida's argument about language maps onto an argument about collective identity formation-even if collective identity constitutively presupposes difference-the Derridean category of the constitutive outside is not coterminous with an empirically specifiable set of concrete individuals. Even granting the Derridean argument, and even if "difference is the condition of the possibility of constituting unity," as Mouffe $(2000,33)$ urges, it does not follow that collective political identities presupposeor that unity can only be forged on the basis of-an "other" consisting of actually existing individuals. Derrida's argument does not even support the weaker version of the particularist thesis, much less the stronger Schmittian one that adds the adversary claim. To derive Mouffe's conclusion to the contrary is to confuse the Derridean language of difference with the Schmittian language of alterity. From the Derridean insight it does not follow that every "us" requires an actually existing "them" in Mouffe's sense.

So it is no surprise that Derrida himself attacks Schmitt's friend/enemy argument on precisely this issue. The slide in Schmitt's argument, from the possibility of the enemy-relation to its putative necessity, is important for Derrida not only because its exposure undermines Schmitt's defence of the adversary claim (step (3) above), but also because to see the possibility of the event of war as an event itself requires a prior identification of who the enemy is, i.e., it presupposes that the enemy consists in an identifiable, recognizable, concrete set of individuals, a kämpfende Gesamtheit von Menschen. As Derrida (1994) puts it, it is absolutely crucial for Schmitt that there be no doubts plaguing the knowledge of " $w h o$ is the friend and who is the enemy" (136). And this takes us to the divided heart of the matter as Derrida sees it: the difference that constitutes identity constitutes identity and so penetrates it so that, ultimately, not only is difference internal to the identity itself, but the distinction between what is internal to the identity and what is external to it is always breaking down. ${ }^{38}$ And if the "constitutive outside" is constitutive of what is inside-if even conceptually there is no pure "inside"- then the (impure) conceptual distinction between friend and enemy (or between "us" and "them") cannot map onto existing, empirically identifiable bounded groups of individuals except through ideological obfuscation. This is because any act of identifying the "friend" will inevitably find

\footnotetext{
37 "Le système de l'écriture [which is the putative "outside" to a langue] en général n'est pas extérieur au système de la langue en général, sauf si l'on admet que le partage entre l'extérieur et l'intérieur passe à l'intérieur de l'intérieur ou à l'extérieur de l'extérieur, au point que l'immanence de la langue soit essentiellement exposée à l'intervention de forces en apparence étrangères à son système" (Derrida 1967, 63).

${ }^{38}$ This is a point that Mouffe herself wants to make as well; the problem is not that she fails to make it, but that she fails to see its incompatibility with her Schmittian conclusions. Her collaborator Ernesto Laclau (1996, chaps. 2,4) also makes the same point about the instability of the inside/outside distinction; but he does not invoke Schmitt.
}

within its members characteristics that supposedly belonged solely to the category of the "enemy." 39 "The contrary of the political inhabits and politicizes the political" (160). On Derrida's deconstructive reading, then, the enemy is "other" only in the expansive sense that allows for the possibility of an other who inhabits the inside. Indeed, ultimately the enemy is "other" only in the radically expansive sense that breaks down the distinction between self and other: the enemy is within one's own self, which is, as Derrida points out, the conclusion to which Schmitt himself comes as a prisoner after World War II (187). This is why, Derrida claims, Schmitt begins by strictly defining the political in terms of antagonism against an external enemy, but ends up internalizing the friend-enemy relation, claiming that the lack of an external enemy would simply internalize war by directing it toward domestic enemies (14042)..$^{40}$

One need not endorse either Derrida's reading of Schmitt or his substantive philosophical argument about difference to see that his argument cannot be used to justify either the exclusion or the adversary claim. There are three distinct reasons why difference does not map onto an empirically identifiable concrete "other" consisting of actually existing persons excluded (whether formally or effectively) from membership. ${ }^{41}$ (1) First, even if identity presupposes difference, difference can exist within the putative inside. (2) Second, difference within the putative inside actually calls into question the sharp distinction between inside and outside. (3) Third, difference need not refer to actually existing persons at all: it can refer to nonhumans, it can refer to characteristics rather than individuals, and it need not refer to actually existing things at all. And the difference argument does not justify the adversary claim because (4) there are no metaphysical grounds for thinking that a relation of difference is necessarily a relation of antagonism (i.e., for thinking that the possibility of war is always effective and structuring).

The result is that the difference argument cannot service Mouffe's neo-Schmittian anticosmopolitanism,

\footnotetext{
39 Derrida (1994, 134) refers to "l'inaccessibilité de la frontière (le partage entre les concepts autant que le partage entre le dedans et le dehors du corps politique...)" and concludes that "en pratique... cette différence entre les différends n'a jamais lieu. On ne la trouve jamais. Jamais concrètement. Introuvable par conséquent demeure la pureté ... de l'ennemi par laquelle Schmitt entend définir le politique....Aucun événement politique ne peut être correctement décrit ou défini à l'aide de ces concepts." The ensuing doubt about who is the friend and who is the enemy generates, according to Derrida (136), "la récurrence compulsive et obsessionnelle du mot «concret»" in Schmitt's text.

${ }^{40}$ See Schmitt 1996, 51, quoted in footnote 27.

${ }^{41}$ Mouffe's $(2000,12)$ own language, when she is consciously attending to the Derridean current of her argument, actually betrays this: she refers, for example, to the "positivity" of the inside being "a function of the symbol of something exceeding it"-and a symbol, of course, is not the same thing as actually existing persons. (Schmitt (1996) himself is emphatic on this point: "The friend and enemy concepts are to be understood in their concrete and existential sense, not as metaphors or symbols" [27-28].) Persons can be symbols, to be sure, and such excluded persons often are the symbols that help constitute collective identities, but this is hardly a conceptual or metaphysical necessity.
} 
on either the strict or the expansive reading: either she means to say that (A) democracy requires an external other qua enemy, in which case she has provided no support for the particularist thesis on which that claim is predicated, or she means to say that (B) democracy requires an enemy whether external or domestic, in which case her point is not specific to global democracy - to say nothing of the fact that the Schmittian defense of this adversary claim conflates possibility and effectivity. The problem of power-in particular, the exclusionary violence that the constitution of any unity leaves as a remainder-is not a problem specific to cosmopolitan democracy. If one can conceive of democratic possibilities at the subglobal level-as Mouffe does, which is the point of her critique of Schmittthen to bar the possibility of a global identity undergirding a democratically legitimated cosmopolitan order requires asserting the particularist thesis found in the strict reading (A). And the problem here is thatdifference argument or not-the particularist thesis does not stand to reason: cosmopolitan solidarity or identity does not require an actually existing external other in contrast to which it must constitute itself.

\section{CONCLUSION}

The particularist thesis has tempted not just theorists directly influenced by Schmitt, but also those under the spell of nationalist ideology: what Schmitt shares in common with nationalists is that both view political life in terms of the ideology of sovereignty. The upshot is that when political claims are made for collective identity groups, they are viewed, in light of the nationalist model, as demands for sovereignty in the modern ideological sense, a sense whose imaginary demands an external other.

But theorists who ground their anticosmopolitanism in the widely held belief that collective identity inherently presupposes an external other are quite mistaken to think that their position rests on a self-evident conceptual or metaphysical truth. Neither the recognition argument, the dialogic argument, the political enemy argument, nor the difference argument provides any support for the particularist thesis. The political enemy argument fails because the argument itself is unsubstantiated: it either depends on definitional fiat, and so begs the question, or it depends on problematic metaphysical assumptions about the effectivity of the possible that reify the causes of antagonism. The other three arguments rest on claims that are more plausible: identity may indeed presuppose recognition, dialogue, or difference. But, contrary to what a cursory examination might suggest, none of these three claims grounds the particularist thesis: the sources of recognition and dialogue required in the formation of a collective identity need not be humans excluded from membership; and difference need not refer to actually existing individuals excluded from membership either. ${ }^{42}$

\footnotetext{
${ }^{42}$ The three arguments are not necessarily mutually compatible. The Derridean difference argument calls into question Hegel's metaphys-
}

While particularists who appeal to the recognition and dialogic arguments are guilty of a fallacy of composition, those who ground the particularist thesis by appeal to "difference" miss the fact that difference and otherness can be constructed not just spatially, as it were, but also imaginatively and temporally (cf. Wendt 2003, 527). We can see this oversight in Chris Brown's (2001, 131) argument:

Identity is about difference. There is no reason why a European identity could not gradually supersede British or French or Portuguese identities, but there is every reason why a global identity could not supersede European or North American or Japanese identities. Such a global identity would have no borders, no frontiers, no sense of the Other.

To be sure, a collective identity might be formed in contrast to, or even in combat with, an actually existing external other excluded from its membership. But it might also be constructed on the basis of difference from hypothetical values and the imagined collective identities centered on them, or on the basis of difference from the values of a past historical identity from which one wishes to mark one's distance. One way to construct European solidarity is to ground it in a Christian-based identity defined in sharp contrast to Europe's Islamic frontiers; a second way is to construct European identity in terms of the political values and institutions of human rights, religious toleration, political freedom, democracy, and so on, that seem increasingly entrenched in Europe since the end of World War II. ${ }^{43}$ The contrast, in the second case, might be with Europe's own history, and with a lingering past that it seeks to leave behind. If identity does indeed presuppose difference, the first mode of constitution is not open to cosmopolitan solidarity, but the second is: humanity's own past provides a rich and terrifying repository in contrast to which cosmopolitan identity could constitute its "difference."

None of this is to deny the empirical fact of actual exclusion, antagonism, and conflict in our world. It is, indeed, an empirically observable phenomenon that collective identities often $d o$ constitute themselves via the exclusion of external others from membership. ${ }^{44}$ Perhaps there are even empirical (psychological, sociological, economic, and political) reasons why collective identities, particularly political collective identities, are most easily formed in this way-at least in the world

\footnotetext{
ical assumptions, about the transparent and holistic nature of selfconsciousness, which undergird the Hegelian recognition argument.

${ }^{43}$ For these two rival myths of European identity and their political implications, see Riekmann 1997.

${ }^{44}$ Eriksen (1995) provides empirical evidence for this phenomenon, even though, like many others, he thinks the empirical phenomenon manifests a deeper conceptual necessity: "It is an obvious fact," his article begins, "that every community is defined in relation to [a] that which it is not; that is, [b] outsiders, aliens, non-members of the group. Social identities and groups are by default [a] relational in the sense that they are defined [b] in relation to other identities, other groups" (427). Notice the illicit slide from (a) the assertion that identity requires contrast or difference to (b) the assertion that this contrast must be with a concrete other. Only the second assertion amounts to the particularist thesis.
} 
as we know it (Mercer 1995). I have already suggested one reason for this: the fact that contemporary politics is dominated by the modern ideology of sovereignty. But one must be careful not to redescribe the empirical phenomena in terms of conceptual or metaphysical necessity. Chantal Mouffe's work is perhaps the most robust attempt by a political theorist to collapse the empirical and conceptual/metaphysical in this regard, and it is in part successful, at least on the surface, because of existing phenomena that make such a description of political dynamics seem accurate. The problem with such a misdescription, however, is that its only function is to reify the politically generated dynamics that, by reference to other possibilities, it is the task of normative political theory to call into question. There is quite literally a world of difference between Miller's (1989a, 67-68) claim that "communities just are particularistic," as if we were confronted with a conceptual or metaphysical truth, and his more careful assessment elsewhere that communities tend to be particular for empirical reasons. ${ }^{45}$ While a merely empirical observation that collective identities have usually been formed contrastively would certainly raise difficulties for cosmopolitanism, those difficulties might turn out to be dependent on contingent (say, structural) features of the current sociopolitical order-and hence in principle surmountable. The falsity of the particularist thesis is crucial here because the anticosmopolitan thesis that a democratic order centered on a global human identity is impossible depends on a feasibility limit that only such a categorical conceptual or metaphysical claim about the inherent nature of collective identity provides.

So if applying the Hegelian, Schmittian, or nationalist paradigms to the process of collective identity formation inevitably leads to a conceptual or metaphysical misdescription of the empirical phenomena, then overcoming such reification may require rethinking these processes within a different theoretical apparatus. Only then might it be possible to better understand under what particular sociopolitical conditions collective identities are likely to be formed through opposition to an external other and, by contrast, under what conditions internally generated collective identities are formed. Thus I see a complementary division of labor between political theorists and philosophers, on the one hand, and empirical social scientists, on the other. It is the primary task of the former to clarify, in light of the empirical evidence, the theoretical possibilities and systematically to assess their desirability; it is the primary task of the latter to investigate the empirical conditions under which the various possibilities might be realized. ${ }^{46}$ Reifying the Westphalian

\footnotetext{
45 "It would be too strong to say that it is necessary to the very idea of community that there must be outside communities in competition, so to speak, with the one with which I identify. Nevertheless, there seems to be a well-supported empirical connection between the strength of people's attachment to their own community and their awareness of rival collectivities" (Miller 1989b, 232-33).

${ }^{46}$ For a good example of the latter, see Fearon and Laitin 2000, who provide an overview and synthesis of some recent literature on ethnic identity formation and violence.
}

order in conceptual or metaphysical terms, to the detriment of the future possibility of a democratically legitimated cosmopolitan political order, is not a gift that a critical political theorist should just hand over to the nation-statist status quo. It certainly does not need the help.

\section{REFERENCES}

Anderson, Benedict. 1991. Imagined Communities: Reflections on the Origin and Spread of Nationalism. Rev. ed. London: Verso.

Balakrishnan, Gopal. 2000. The Enemy: An Intellectual Portrait of Carl Schmitt. London: Verso.

Brown, Chris. 2001. "Borders and Identity in International Relations Theory." In Identities, Borders, Orders: Rethinking International Relations Theory, ed. Mathias Albert, David Jacobson, and Yosef Lapid. Minneapolis: University of Minnesota Press, 117-36.

Bull, Hedley. 1977. The Anarchical Society: A Study of Order in World Politics. New York: Macmillan and Columbia University Press.

Cohen, Jean L. 1999. "Changing Paradigms of Citizenship and the Exclusiveness of the Demos." International Sociology 14 (September): 245-68

Connolly, William E. 1991. Identity $\backslash$ Difference: Democratic Negotiations of Political Paradox. Ithaca, NY: Cornell University Press.

Derathé, Robert. 1970. Jean-Jacques Rousseau et la science politique de son temps. 2nd ed. Paris: Librairie Philosophique J. Vrin.

Derrida, Jacques. 1967. De la grammatologie. Paris: Éditions de Minuit.

Derrida, Jacques. 1994. Politiques de l'amitié, suivi de L'oreille de Heidegger. Paris: Galilée.

Eriksen, Thomas Hylland. 1995. "We and Us: Two Modes of Group Identification." Journal of Peace Research 32 (November): 427-36.

Fearon, James D., and David D. Laitin. 2000. "Violence and the Social Construction of Ethnic Identity." International Organization 54 (Autumn): 845-77.

Giddens, Anthony. 1987. The Nation-State and Violence: Volume Two of A Contemporary Critique of Historical Materialism. Berkeley: University of California Press.

Gilpin, Robert G. 1986. "The Richness of the Tradition of Political Realism.” In Neorealism and Its Critics, ed. Robert O. Keohane. New York: Columbia University Press.

Greenfeld, Liah. 1992. Nationalism: Five Roads to Modernity. Cambridge, MA: Harvard University Press.

Habermas, Jürgen. 1987. The Theory of Communicative Action. Vol. 2. Boston: Beacon Press.

Hegel, Georg Wilhelm Friedrich. 1977. Phenomenology of Spirit, ed J. N. Findlay. Trans. A. V. Miller. Oxford: Oxford University Press.

Hegel, Georg Wilhelm Friedrich. 1991. Elements of the Philosophy of Right, ed. Allen W. Wood. Trans. H. B. Nisbet. Cambridge: Cambridge University Press.

Held, David. 1995. Democracy and the Global Order: From the Modern State to Cosmopolitan Governance. Stanford, CA: Stanford University Press.

Hinsley, F. H. 1986. Sovereignty. 2nd ed. Cambridge: Cambridge University Press.

Hobbes, Thomas. [1651] 1996. Leviathan, ed. Richard Tuck. Rev. student ed. Cambridge: Cambridge University Press.

Huntington, Samuel P. 1996. The Clash of Civilizations: Remaking of World Order. New York: Touchstone.

Jaeggi, Rahel. 2001. "Solidarity and Indifference." In Solidarity in Health and Social Care in Europe, ed. Rudd Ter Meulen, Wil Arts, and Ruud Muffels. Dordrecht, the Netherlands: Kluwer, 287-308.

Jepperson, Ronald L., Alexander Wendt, and Peter J. Katzenstein. 1996. "Norms, Identity, and Culture in National Security." In The Culture of National Security: Norms and Identity in World Politics, ed. Peter J. Katzenstein. New York: Columbia University Press, 33-75.

Kant, Immanuel. [1797] 1996. Metaphysics of Morals. In The Cambridge Edition of the Works of Immanuel Kant: Practical Philosophy, ed. Mary J. Gregor. Cambridge: Cambridge University Press.

Krasner, Stephen D. 1988. "Sovereignty: An Institutional Perspective." Comparative Political Studies 21 (April): 66-94. 
Krasner, Stephen D. 1995. "Compromising Westphalia." International Security 20 (Winter): 115-51.

Krasner, Stephen D. 1999. Sovereignty: Organized Hypocrisy. Princeton, NJ: Princeton University Press.

Laclau, Ernesto. 1996. Emancipation(s). London: Verso.

Lefort, Claude. 2000. "Nation et souveraineté." Les Temps Modernes 55 (Septembre-Octobre-Novembre): 25-46.

Mason, Andrew. 2000. Community, Solidarity and Belonging. Cambridge: Cambridge University Press.

Mercer, Jonathan. 1995. "Anarchy and Identity." International Organization 49 (Spring): 229-52.

Miller, David. 1989a. "In What Sense Must Socialism Be Communitarian?" Social Philosophy \& Policy 6 (Spring): 51-73.

Miller, David. 1989b. Market, State, and Community: Theoretical Foundations of Market Socialism. Oxford: Clarendon Press.

Mouffe, Chantal. 1993. The Return of the Political. London: Verso.

Mouffe, Chantal. 2000. The Democratic Paradox. London: Verso.

Philpott, Daniel. 1995. "Sovereignty: An Introduction and Brief History." Journal of International Affairs 48 (Winter): 353-68.

Rée, Jonathan. 1998. "Cosmopolitanism and the Experience of Nationality." In Cosmopolitics: Thinking and Feeling Beyond the Nation, ed. Pheng Cheah and Bruce Robbins. Minneapolis: University of Minnesota Press, 77-90.

Ricoeur, Paul. 1991. Lectures 1: Autour du politique. Paris: Éditions du Seuil.

Riekmann, Sonja Puntscher. 1997. "The Myth of European Unity." In Myths and Nationhood, ed. Geoffrey Hosking and George Schöpflin. New York: Routledge, 60-71.

Ruggie, John Gerard. 1993. "Territoriality and Beyond: Problematizing Modernity in International Relations." International Organization 47 (Winter): 139-74.

Saussure, Ferdinand de. 1960. Cours de linguistique générale, ed. Charles Bally and Albert Sechehaye. 5th ed. Paris: Payot.

Schmitt, Carl. 1922. Politische Theologie: Vier Kapitel zur Lehre von der Souveräntät. Munich: Duncker \& Humbolt.

Schmitt, Carl. 1985a. Political Theology: Four Chapters on the Concept of Sovereignty. Trans. George Schwab. Cambridge, MA: MIT Press.

Schmitt, Carl. 1985b. The Crisis of Parliamentary Democracy. Trans. Ellen Kennedy. Cambridge, MA: MIT Press.

Schmitt, Carl. 1987. Der Begriff des Politischen: Text von 1932 mit einem Vorwort und drei Corollarien. Berlin: Duncker \& Humbolt.
Schmitt, Carl. 1996. The Concept of the Political. Trans. George Schwab. Chicago: Chicago University Press.

Schnapper, Dominique. 1994. La Communauté des citoyens: Sur l'idée moderne de nation. Paris: Gallimard.

Smith, Anthony D. 1990. "Towards a Global Culture?" Theory, Culture \& Society 7 (June): 171-91.

Smith, Anthony D. 1992. "National Identity and the Idea of European Unity." International Affairs 68 (January): 5576.

Spruyt, Hendrik. 1994. "Institutional Selection in International Relations: State Anarchy as Order." International Organization 48 (Autumn): 527-57.

Taylor, Charles. 1975. Hegel. Cambridge: Cambridge University Press.

Taylor, Charles. 1994. "The Politics of Recognition.” In Multiculturalism: Examining the Politics of Recognition, ed. Amy Gutmann. Princeton, NJ: Princeton University Press.

Taylor, Charles. 1998. "The Dynamics of Democratic Exclusion." Journal of Democracy 9 (October): 143-56.

Taylor, Talbot J. 1992. Mutual Misunderstanding: Scepticism and the Theorizing of Language and Interpretation. Durham, NC: Duke University Press.

Tuck, Richard. 1989. Hobbes. Oxford: Oxford University Press.

Walker, R. B. J. 1993. Inside/Outside: International Relations as Political Theory. Cambridge: Cambridge University Press.

Walzer, Michael. 1992. "The New Tribalism: Notes on a Difficult Problem." Dissent 39 (Spring): 164-71.

Weber, Eugene. 1976. Peasants into Frenchmen: The Modernization of Rural France, 1870-1914. Stanford, CA: Stanford University Press.

Wendt, Alexander. 1992. "Anarchy Is What States Make of It: The Social Construction of Power Politics." International Organization 46 (Spring): 391-425.

Wendt, Alexander. 1999. Social Theory of International Politics. Cambridge: Cambridge University Press.

Wendt, Alexander. 2003. "Why a World State Is Inevitable." European Journal of International Relations 9 (December): 491542.

Wenman, Mark Anthony. 2003. "What Is Politics? The Approach of Radical Pluralism.” Politics 23 (February): 57-65.

Wood, Allen. 1990. Hegel's Ethical Thought. Cambridge: Cambridge University Press. 